ARTIKEL

\title{
IMPLEMENTASI KEBIJAKAN MENTERI AGRARIA DAN TATA RUANG TENTANG PERCEPATAN PELAKSANAAN PENDAFTARAN TANAH SISTEMATIS LENGKAP DI KOTA BANDUNG
}

\author{
Asep Hidayat, Engkus, Hasna Afra. N \\ dr.asephi@uinsgd.ac.id, afrahasna29@gmail.com
}

\begin{abstract}
This research aims to know the strategy of the Government in the implementation of the programme of PTSL and to find out how big a success rate of Program execution PTSL in Bandung. The results showed that the Government strategy of Bandung Bandung in BPN through program implementation through the preparation of PTSL ripe includes socialization, the determination of the location, planning effort, and the establishment of the Committee ajudikasi acceleration, training and outreach. The success rate of execution of PTSL in Bandung from the target amount of the targeted land certificate 93,000 just 7,234 certificate or reached only 7.78\% of the data that researchers get. This is caused by a number of working groups, the situation is not comparable with the volume so that the targets set in the achievement of the targets still not be met.
\end{abstract}

Keywords : Implementation Of Policy, PTSL, BPN, Land.

\begin{abstract}
Abstrak
Penelitian ini bertujuan untuk mengetahui strategi pemerintah dalam pelaksanaan Program PTSL dan untuk mengetahui seberapa besar tingkat keberhasilan pelaksanaan Program PTSL di Kota Bandung. Hasil penelitian menunjukkan bahwa strategi yang dilakukan pemerintah Kota Bandung melalui BPN Kota Bandung dalam pelaksanaan program PTSL yaitu melalui persiapan yang matang mencangkup sosialisasi, penetapan lokasi, perencanaan tenaga, dan pembentukan panitia ajudikasi percepatan, pelatihan dan penyuluhan. Tingkat keberhasilan pelaksanaan PTSL di Kota Bandung yaitu dari jumlah target 93.000 sertifikat tanah yang ditargetkan hanya 7.234 sertifikat atau hanya mencapai $7,78 \%$ dari data yang peneliti dapatkan. Hal ini disebabkan oleh jumlah kelompok kerja dilapangan tidak sebanding dengan volume target yang ditetapkan sehingga dalam pencapaian target masih belum bisa terpenuhi.
\end{abstract}

Kata Kunci : Implementasi Kebijakan; Pendaftaran Tanah Sistematis Lengkap; Badan Pertanahan Nasional; Tanah.

\section{A. PENDAHULUAN}

Secara umum Negara Indonesia merupakan negara agraris yang memiliki hasil bumi yang melimpah dan negara kepulauan yang memiliki hasil laut yang beraneka ragam, Indonesia juga kaya akan hasil tambang sehingga apabila diolah secara efektif dan efesien dapat menghasilkan nilai ekonomi yang tinggi. Dalam konteks pertanahan, tanah merupakan permukaan bumi yang berupa daratan tempat manusia berdiri, bertempat tinggal, bercocok tanam dan segala jenis usaha untuk mempertahankan 
kelangsungan hidupnya juga yang terpenting adalah tempat dimana suatu negara berdiri untuk melindungi, mengayomi rakyatnya dan untuk mencapai tujuan hidup yaitu kemakmuran dan kesejahteraan melalui usaha yang dilakukan oleh pemerintah.

Tanah merupakan salah satu sumber penghidupan dan mata pencaharian bagi manusia sehingga menjadi kebutuhan yang paling mendasar, dengan keyakinan betapa sangat dihargai dan bermanfaat tanah untuk kehidupan manusia, bahkan tanah dan manusia tidak dapat dipisahkan. Manusia hidup dan berkembang serta melakukan aktivitas di atas tanah sehingga setiap saat manusia berhubungan dengan tanah (M.P. Siahan, 2003: 1). Tanah yang merupakan salah satu sumber daya alam penghasil barang dan jasa serta berperan penting sekali bagi penghidupan dan kehidupan manusia, bahkan menentukan peradaban suatu bangsa. Peradaban itu akan berlangsung kebesarannya selama bangsa itu menggunakan tanah dan sumber daya alam lainnya secara bijaksana (Soedjarwo Soemihardjo, 2009: 105).

Pertanahan (tanah) adalah sesuatu yang menjadi suatu kebutuhan yang pokok dalam kehidupan manusia. Dalam menjalani kehidupannya, manusia selalu berkaitan dengan tanah, mulai dari tanah untuk tempat tinggalnya, tempat usahanya, hingga sampai ujung kehidupannya di dunia (kuburan/pemakaman) selalu berkaitan dengan pertanahan. Disebabkan oleh alasan tersebut, tanah menjadi suatu hal yang sangat berharga dan penting bagi manusia, sehingga sering menyebabkan perselisihan dan pertikaian antar sesama manusia, bahkan antara keluarga sering menyebabkan perpecahan karena masalah pertanahan ini. Lebih kompleks lagi, pertikaian pertanahan ini juga bisa terjadi antara negara-negara yang saling berbatasan.

Tanah tidak bisa dipisahkan dari kehidupan manusia. Secara ekstrim dapat dikatakan bahwa tanpa tanah tidak ada kehidupan, dalam kata lain tanah memiliki arti dan fungsi yang sangat penting bagi kehidupan manusia. Sementara Bangsa Indonesia yang pada saat ini sedang giat-giatnya melaksanakan pembangunan sangat banyak membutuhkan tanah atau lahan tempat untuk membangun, dimana tanah mempunyai peran yang sangat penting dalam kehidupan manusia, dan peranan itu akan dirasakan semakin penting sejalan dengan tuntutan laju pembangunan diberbagai bidang dan tingkat kemajuan dalam masyarakat itu sendiri.

Menyadari betapa pentingnya tanah bagi hidup dan kehidupan manusia maka dari itu Menteri Agraria dan Tata Ruang melalukan Program Percepatan Pelaksanaan 
Pendaftaran Tanah Sistematis Lengkap (PTSL), sesuai dengan perencanaan yang tertuang dalam Keputusan Menteri Agraria dan Tata Ruang/Kepala Badan Pertanahan Nasional Nomor 35 Tahun 2016 tentang Percepatan Pelaksanaan PTSL yang diharapkan dapat membantu masyarakat untuk mendapatkan hak atas tanah sebagai bukti kepemilikan. PTSL adalah kegiatan pendaftaran tanah untuk pertama kali yang dilakukan secara serentak yang meliputi semua objek pendaftaran tanah yang belum didaftar dalam suatu wilayah desa/kelurahan atau nama lainnya yang setingkat dengan itu. Objek Pendaftaran PTSL ini meliputi seluruh bidang tanah tanpa terkecuali, baik yang belum bersertifikat ataupun yang bersertifikat (tetapi belum terpetakan) sehingga tercipta peta lengkap.

Peningkatan persentase tanah terdaftar yang saat ini masih di bawah 50\% (secara nasional), adapun pendaftaran tanah sistematik lengkap yang meliputi wilayah satu kabupaten/kota akan dilaksanakan di 3 kota yaitu Kota Bandung sebanyak 93.000 sertifikat, Kota Cimahi sebanyak 40.000 sertifikat dan Kota Sukabumi sebanyak 11.000 sertifikat. Kota Bandung menjadi salah satu pemerintah daerah yang melaksanakan Percepatan PTSL melalui Kantor Pertanahan Kota Bandung.

\section{B. Tinjauan Teori}

Tanah merupakan salah satu sumber penghidupan dan mata pencaharian bagi manusia sehingga menjadi kebutuhan yang paling mendasar, dengan keyakinan betapa sangat dihargai dan bermanfaat tanah untuk kehidupan manusia, bahkan tanah dan manusia tidak dapat dipisahkan. Manusia hidup dan berkembang serta melakukan aktivitas di atas tanah sehingga setiap saat manusia berhubungan dengan tanah (M.P. Siahan, 2003: 1). Tanah yang merupakan salah satu sumber daya alam penghasil barang dan jasa serta berperan penting sekali bagi penghidupan dan kehidupan manusia, bahkan menentukan peradaban suatu bangsa. Peradaban itu akan berlangsung kebesarannya selama bangsa itu menggunakan tanah dan sumber daya alam lainnya secara bijaksana (Soedjarwo Soemihardjo, 2009: 105).

Tahapan percepatan pelaksanaan PTSL berdasarkan Peraturan Menteri Agraria dan Tata Ruang/Badan Pertanahan Nasional Nomor 35 Tahun 2016 Pasal 3 yaitu penetapan lokasi kegiatan Percepatan PTSL, pembentukan panitia ajudikasi percepatan, pengumpulan data fisik dan data yuridis bidang tanah, pembuktian hak serta 
ARTIKEL

pembukuan hak atas tanah, dan penerbitan sertifikat hak atas tanah bagi yang memenuhi syarat.

\section{PEMBAHASAN}

Menteri Agraria dan Tata Ruang melalukan Program Percepatan Pelaksanaan PTSL, sesuai dengan perencanaan yang tertuang dalam Keputusan Menteri Agraria dan Tata Ruang/Kepala Badan Pertanahan Nasional Nomor 35 Tahun 2016 tentang Percepatan Pelaksanaan PTSL yang diharapkan dapat membantu masyarakat untuk mendapatkan hak atas tanah sebagai bukti kepemilikan. Pendaftaran Tanah Sistematis Lengkap adalah kegiatan pendaftaran tanah untuk pertama kali yang dilakukan secara serentak yang meliputi semua objek pendaftaran tanah yang belum didaftar dalam suatu wilayah desa/kelurahan atau nama lainnya yang setingkat dengan itu. Objek PTSL ini meliputi seluruh bidang tanah tanpa terkecuali, baik yang belum bersertifikat ataupun yang bersertifikat (tetapi belum terpetakan) sehingga tercipta peta lengkap.

Tahapan percepatan pelaksanaan PTSL berdasarkan Peraturan Menteri Agraria dan Tata Ruang/Badan Pertanahan Nasional Nomor 35 Tahun 2016 Pasal 3 yaitu penetapan lokasi kegiatan Percepatan Pelaksaaan Pendaftaran Tanah Sistematis Lengkap, pembentukan Panitia Ajudikasi Percepatan, pengumpulan data fisik dan data yuridis bidang tanah, pembuktian hak serta pembukuan Hak Atas Tanah, dan penerbitan sertifikat hak atas tanah bagi yang memenuhi syarat.

Mengimplementasikan kebijakan publik, ada dua pilihan langkah yang ada, yaitu langsung mengimplementasikan dalam bentuk program atau melalui formulasi derivat atau turunan dari kebijakan publik tersebut. rangkaian implementasi kebijakan dapat diamati dengan jelas yaitu dimulai dari program dan ke kegiatan. Merilee S. Grindle yang menyebutkan bahwa keberhasilan implementasi dipengaruhi oleh dua variabel besar, yakni isi kebijakan dan lingkungan implementasi. Pengunaan teori tersebut dapat membantu peneliti unjuk menganalisis Implementasi Kebijakan Menteri Agraria dan Tata Ruang/ Kepala Badan Peranahan Nasional Nomor 35 Tahun 2016 tentang Percepatan Pelaksanaan Pendaftaran Tanah Sistematis Lengkap (PTSL).

Metode penelitian yang digunakan dalam penelitian ini adalah penelitian kualitatif dengan pendekatan analisis deskriptif. Subjek dalam penelitian ini yaitu Ketua 
Pelaksana PTSL Kota Bandung, Pelaksana Teknis, dan perwakilan masyarakat. Teknik pengumpulan data yang digunakan dalam penelitian ini adalah wawancara, observasi, dan analisis dokumen. Teknik analisi data dalam penelitian ini meliputi pengumpulan data, reduksi data, penyajian data, dan penarikan kesimpulan.

Berdasarkan data yang peneliti dapat, dapat diketahui setelah berjalannya Percepatan Pelaksanaan PTSL di Kota Bandung bahwa jumlah sertifikat bidang tanah bersertifikat namun belum terdaftar (K4) sebanyak 12.082 sertifikat, kemudian data yuridis memenuhi syarat namun subjek tidak memenuhi syarat (K3) sebanyak 35.679 subjek, dan sertifikat yang sudah terbit (K1) sebanyak 7.234 atau hanya mencapai 7,78 $\%$ dari target yang telah di tetapkan oleh pemerintah sebanyak 93.000 sertifikat tanah di Kota Bandung. Hal ini diakibatkan karena jumlah kelompok kerja dilapangan tidak sebanding dengan volume target yang ditetapkan, sehingga kinerja kelompok kerja dalam pelaksanaannya tidak berjalan dengan maksimal. Sertifikat kepemilikan tanah sangat penting bagi masyarakat, karena sebagai bukti jaminan kepastian hukum atas hak tanah.

Kota Bandung merupakan salah satu Daerah yang telah melaksanakan kebijakan atau program Percepatan Pelaksanaan Pendaftaran Tanah Sistematis Lengkap. Target yang telah ditetapkan dalam menjalankan program tersebut berjumlah 93.000 sertifikat. Berdasarkan hasil penelitian dan analisis diatas, bahwa strategi yang telah dijalankan dalam menunjang program tersebut, BPN Kota Bandung menerapkan strategi sesuai dengan yang tercantum dalam Petunjuk Teknis Pelaksanaan PTSL. Strategi tersebut yaitu, persiapan mencangkup sosialisasi, penetapan lokasi, perencanaan tenaga, dan pembentukan panitia ajudikasi percepatan, pelatihan dan penyuluhan.

Sosialisasi dalam persiapan ini dilakukan oleh seluruh jajaran Kementerian Agraria dan Tata Ruang/ Badan Pertanahan Nasional yang memberikan informasi akan dilaksanakannya Percepatan Pelaksanaan PTSL kepada masyarakat secara langsung melalui media. Penetapan lokasi dan jumlah bidang ditetapkan dengan memperhatikan ketersediaan peta kerja, ketersediaan dan kemampuan optimal panitia dan satgas, juga lokasi diupayakan agar desa yang menjadi obyek PTSL letaknya berdekatan. 
Perencanaan tenaga panitia dan Satgas Yuridis juga sebagai salah satu persiapan dalam Pelaksanaan Percepatan PTSL. Satu panitia dalam Pelaksanaan Percepatan PTSL disebut panitia ajudikasi percepatan, berjumlah 4 orang pegawai Badan Pertanahan Nasional ditambah satu dari Kelurahan/Desa, dan kenaggotaannya dapat ditambah sesuai kebutuhan. Setelah pembentukan panitia ajudikasi untuk mempersiapkan kelancaran Pelaksanaan PTSL, perlu dilakukan pelatihan teknis "Pendaftaran Tanah Sistematis Bidang Yuridis", bagi panitia Ajudikasi Percepatan dan Satgas Yuridis yang meliputi materi pengumpulan data yuridis, pengolaan data yurudis dan tata laksana kegiatan PTSL, yang dilaksanakan oleh Kantor Wilayah Badan Pertanahan Nasional Provinsi.

Penyuluhan sangat penting dilakukan dalam mempersiapkan Pelaksanaan PTSL, penyuluhan dilakukan selambat-lambatnya pada bulan kedua (B.2). penyuluhan dilakukan oleh Kantor Pertanahan beserta Panitia Ajudikasi Percepatan dan Satgas Yuridis bersama Satgas fisik. Dalam penyuluhan disampaikan tahapan kegiatan PTSL, dokumen yuridis yang perlu disiapkan, jadwal pengumpulan data yuridis, kluster hasil akhir kegiatan ajudikasi percepatan. Mengajak partisipasi masyarakat dalam Pelaksanaan PTSL dengan memperhatikan Hak dan Kewajibannya. Serta menjelaskan tentang pembiayaan yang disediakan oleh Pemerintah melalui kegiatan PTSL dan kemungkinan biaya/bea/pajak yang akan ditanggung oleh peserta.

Strategi yang dilakukan oleh BPN dalam Percepatan Pelaksanaan PTSL sangat tertata, sesuai aturan dan petunjuk yang telah ditetapkan. Namun dalam penelitian ini dirasa hasil dari pencapaian target yang tidak terpenuhi. Berdasarkan hasil penelitian dari jumlah target 93.000 sertipikat tanah yang ditargetkan oleh Pemerintah hanya mencapai 7.234 atau hanya mencapai 7,78 \% dari data yang peneliti dapatkan. Hal ini disebabkan oleh jumlah kelompok kerja dilapangan tidak sebandung dengan volume target yang ditetapkan sehingga dalam pencapaian target masih belum bisa terpenuhi.

\section{SIMPULAN}

Berdasarkan hasil penelitian dan analisis data bahwa implementasi kebijakan Menteri Agrararia dan Tata Ruang / Kepala Badan Pertanahan Nasional Nomor 35 tahun 2016 tentang Percepatan Pelaksanaan Pendaftaran Tanah Sistematis Lengkap di 
Kota Bandung dapat disimpulkan sebagai berikut:

Strategi yang dilakukan pemerintah Kota Bandung melalui BPN Wilayah Kota Bandung dalam pelaksanaan program PTSL yaitu melalui persiapan yang matang mencangkup sosialisasi, penetapan lokasi, perencanaan tenaga, dan pembentukan panitia ajudikasi percepatan, pelatihan dan penyuluhan.

Tingkat keberhasilan pelaksanaan PTSL di Kota Bandung yaitu dari jumlah target 93.000 sertifikat tanah yang ditargetkan hanya 7.234 sertifikat atau hanya mencapai $7,78 \%$ dari data yang peneliti dapatkan. Hal ini disebabkan oleh jumlah kelompok kerja dilapangan tidak sebanding dengan volume target yang ditetapkan sehingga dalam pencapaian target masih belum bisa terpenuhi. 


\section{DAFTAR PUSTAKA}

Engkus. (2017). Administrasi Kepegawaian Indonesia Pada Sektor Publik (Dalam Pendekatan Aparatur Sipil Negara). Bandung : FISIP UNPAS PRESS.

Harsono, Budi. (2009). Hukum Agraria Indonesia. Jakarta: Penerbit Djambatam

Keban, Yeremias T. (2008). Enam Dimensi Strategis Administrasi Publik: Konsep,

Teori, dan Isu. Yogyakarta: Gavamedia

Moleong, M.A. (2011) Metodologi Penelitian Kualitatif. Bandung :Remaja Rosdakarya.

Pasolong, Harbani. (2014.)Teori Administrasi Publik. Bandung: Alfabeta

Prastowo, Andi. (2010). Menguasai Teknik-teknik Koleksi Data Penelitian Kualitatif. Yogyakarta: DIVA Press

Siahan, M.P. (2003). Bea Perolehan Hak Atas Tanah Dan Bangunan. Jakarta: Rajawali Pers

Sinambela, Lijan P. (2006). Reformasi Pelayanan Publik: Teori, Kebijakan, dan Implementasi. Jakarta: Bumi Aksara

Soemihardjo, Soedjarwo (2009). Mengkritisi Undang-undang Pokok Agraria. Meretas Jalan Menuju Penataan Kembali Politik Agraria Nasional. Jakarta: Cerdas Pustaka

Subarsono, A.G. (2005). Analisis Kebijakan Publik: Konsep, Teori, dan Aplikasi. Yogyakarta: Pustaka Pelajar

Yogyakarta: Pustaka Pelajar

Sugiyono. (2012). Metode Penelitian Kuantitatif Kualitatif R\&D. Bandung: Alfabeta

Supriadi. (2010). Hukum Agraria. Cet IV. Jakarta : Sinar Grafika

Urip Santos. (2009). Hukum Agraria dan Hak-Hak Atas Tanah, Cet.V. Jakarta :

Kencana

Usman \& Akbar. (2009). Metode Penelitian Sosial. Jakarta: Bumi Aksara

Waskito dan Hadi Arnowo. (2015). Cara Praktis Memahami Bidang Agraria (Pertanahan). Jakarta Timur : Media Adji Internasional

Winarno, Budi. (2007). Kebijakan Publik: Teori Dan Proses. Edisi Revisi. Jakarta : Buku Kita 
ARTIKEL

Jurnal

Andi Armansyah Akbar (2017). Surat Keterangan Tanah Sebagai Syarat Penyertipikatan Tanah

Skripsi

Dimas Yoga Pangestu (2016). Evektifitas Proses Dalam PRONA (Program Nasional Agraria) Di Kantor Pertanahan Kabupaten Sragen.

Eko Budi Wahyono (2017). Implementasi Regulasi Tentang Surveyor Kadaster

Berlisensi Dalam Percepatan Pendaftaran Tanah Di Kantor Wilayah Badan Pertanahan Nasional Provinsi Sumatera Utara.

Muhammad Iqbal (2016). Evektifitas Kinerja Kantor Pertanahan Kabupaten Sambas

Dalam Kegiatan Penyelenggaraan Pendaftaran Tanah Demi Menjamin Kepastian Hukum Hak Atas Tanah.

Jurnal:

Engkus.(2017) 'Implementasi Undang-undang Perdagangan : Implikasinya Dalam Kebijakan Pengendalian Harga Kebutuhan Pokok Masyarakat"dalam Jurnal LITIGASI 18 (1). pp. 1-144. Bandung: UNPAS Bandung.

Engkus.(2017) "Budaya Panengen Sebagai Representasi Simbolik Kepemimpinan Desa Cikalong” dalam Jurnal Ilmiah seni dan budaya Panggung Vol.27 No.2 Juni 2017.Bandung:ISBI Bandung.

Engkus. (2017). "Perilaku Narsis Pada Media Sosial Di Kalangan Remaja Pelajar dan Upaya Penanggulangannya di Wilayah Bandung Timur'.Dalam Jurnal Penelitian Komunikasi Vol 20 No 2 Desember 2017:Bandung: BPPKB Bandung.

Chotim, E. R. (2018). KEBIJAKAN BANDUNG TRANSIT AREA (BTA) UNTUK PENINGKATAN KUNJUNGAN WISATA. TEMALI: Jurnal Pembangunan Sosial, 1(1), 33-57.

Sari, A. L. (2017). THE ROLE OF SOCIAL WORKERS IN THE DEVELOPMENT OF TOURISM VILLAGES. JISPO: Jurnal Ilmu Sosial dan Ilmu Politik, 7(2), 1-23. 


\section{Peraturan Perundang-undangan}

Peraturan Menteri Agraria Dan Tata Ruang/Kepala Badan Pertanahan Nasional Nomor 35 Tahun 2016 tentang Percepatan Pelaksanaan Pendaftaran Tanah Sistematis Lengkap

Undang- Undang Nomor 5 Tahun 1960 tentang Peraturan Dasar Pokok-Pokok Agraria

Peraturan Pemerintah Nomor 24 Tahun 1997 tentang Pendaftaran Tanah

Peraturan Presiden Nomor 17 Tahun 2015 tentang Kementerian Agraria dan Tata Ruang dan Peraturan Presiden Nomor 20 tahun 2015 tentang Badan Pertanahan Nasional

Peraturan Menteri Agraria dan Tata Ruang/ Kepala Badan Pertanahan Nasional Nomor 3 Tahun 1997 tentang Ketentuan Pelaksanaan Peraturan Pemerintah Nomor 24 Tahun 2997 tentang Pendaftaran Tanah

Peraturan Menteri Agraria dan Tata Ruang/ Kepala Badan Pertanahan Nasional Nomor 35 Tahun 2016 tentang Percepatan Pelaksanaan Pendaftaran Tanah Sistematis Lengkap.

Peraturan Menteri Agraria dan Tata Ruang/ Kepala Badan Pertanahan Nasional Nomor 33 Tahun 2016 tentang Surveyor Kadasteral Berlisensi

Internet

http://abdiprojo.blogspot.co.id/2010/04/model-model-impementasikebijakan_05.html (Tanggal 12 Agustus 2012)

$\begin{array}{llll}\text { Kamus } & \text { Besar } \quad \text { Bahasa }\end{array}$ http://pusatbahasa.kemdiknas.go.id/kbbi/(tanggal 10 November 2016) 